kept in a sightly condition and that the bronze tablets, through the ignorance of someone, have been coated with a preparation of black paint which should be skillfully removed and the monument and grounds hereafter maintained perpetualiy in a way appropriate to the spirit in which they were provided and dedicated; therefore

Resolved, That the Curator of the Historical Department be and he hereby is, subject to proper provisions approved in writing by the Board of Trustees of the Historical Department of Iowa, directed to assume and continue control and responsibility as Trustee of the State of Iowa for said monument and grounds.

The above resolution was unanimously adopted by the Council.

Yours very truly,

R. E. JOHNSON, Secretary.

\title{
GEORGIA AND IOWA MARRIAGES, 1864
}

World annals teem with instances of attachments of the sons and daughters of victors with sons and daughters of vanquished. Iowa and Georgia had their examples as evidenced in the marriage records of Clarke County, Iowa, by the returns following: FIRST RECORD BOOK OF MARRIAGES OF CLARKE COUNTY, IOWA

Office Provost Marshall

Rome Georgia, 15th Aug. 1864.

To Any Chaplain in the Armies of the United States.

\} GREETIN G.

By virtue of Authority in me vested, I hereby authorize you to unite in the Holy Bands of Wedlock, Pvt John Reynolds, 39th Inf Iowa Vol.g\& Miss Elizabeth Wallace, of Floyd Co. Ga.

By Order of

Brig Gen Wm. Vancleave

Josiah Rollins

Capt. \& Prvt Marshal

Floyd County, Ga., 17th $\Lambda$ ug 1864

By virtue of authority in me vested, Mr John Reynolds, Member of Company D 39th Iowa Infantry Vol \& Miss Elizabeth Wallace of Floyd County Georgia, have this day been united in the Holy Bands of Wedlock.

Eld. A. H. Chase

We the undersigned members of Company D 39th Iowa Infty Vol hereunto subscribe our names as witnesses to the above.

A. E. Chase

William L. Chaney

John C. Johnson 
Office Provost Marshal

Rome Georgia, 29th Sept. 1864.

To Any Provost Marshal,

Chaplain in U.S. Army,

Or Regularly Ordained

Minister of the Gospel.

G R E E T I N G

You are hereby authorized to unite in the Holy Bands of Wedlock, Pvt., Samuel S. Mackey, 39th Iowa Infty., and Miss Mary Gaddis of Georgia.

By Order of

Brig Gen. Vancleave

Josiah Rollins, Jr.

Capt. \& Prvt Marshall

Floyd Co., Ga. 29th Sept 1864

This is to certify that I have this day united in the Holy Bonds of Matrimony, Priv., Samuel S. Mackey of Co D, 39th Iowa Infty \& Miss Mary Gaddis, of Georgie by virtue of authority in me vested.

Eld. A. H. Chase

WITNESSES $\left\{\begin{array}{l}\text { A. E. Chase. Serg Co D 39th Ia. } \\ \text { L. D. Bennett, Capt Co D 39th Iowa V.I. } \\ \text { Casper Carter, 2nd Lieut Co D 39th Iowa. }\end{array}\right.$

\section{ABSTRACT OF THE MINUTES OF THE STATE BOARD OF CONSERVATION \\ July 14, 1922}

This meeting was held at Boone and D. C. Chase, Jr., J. D. Wardle, Mr. Parsons, and Mr. Van Meter appeared before the Board in the interests of the Iowa Traction Company of Cedar Rapids and presented their plan and petition to construct a dam on the Des Moines River some three miles below the Ledges State Park, which would flood some 150 acres of said park. The Board accompanied these gentlemen to the park to view the land proposed to be submerged.

Motions.-The following motions passed: That the Traction Company be requested to provide the Board with copies of the proceedings on their application in District Court of Boone County, with eight copies of maps showing the present condition of the river with low and high water contours, and showing the conditions proposed, and that marks upon the ground showing the contour lines drawn upon the maps be placed at conspicuous places around the proposed lake and that the Board then call in representatives of the Landscape Engineering Department at Ames and any other experts the Board may desire to advise with; that $\mathrm{Mr}$. Henning be authorized to employ $\mathrm{Mr}$. Hoffman with his team at seventy-five cents an hour to improve the 
Copyright of Annals of Iowa is the property of State of Iowa, by \& through the State Historical Society of Iowa and its content may not be copied or emailed to multiple sites or posted to a listserv without the copyright holder's express written permission. However, users may print, download, or email articles for individual use. 